Şırnak Üniversitesi

Ilahiyat Fakültesi Dergisi

Cilt: 10, Sayı: 23, Aralık 2019

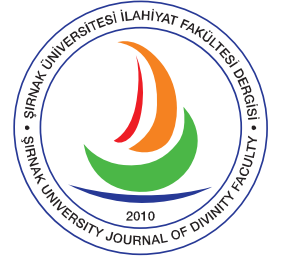

e-ISSN 2667-6575
Şırnak University

Journal of Divinity Faculty

Vol.: 10, Issue: 23, December 2019

\title{
Ottoman Justice Thought in Tanzimat Period and Transitional Justice: A Comparative Analysis
}

Tanzimat Dönemi Osmanlı Adalet Düşüncesi ve Geçiş Dönemi Adaleti: Karşılaştırmalı Bir İnceleme

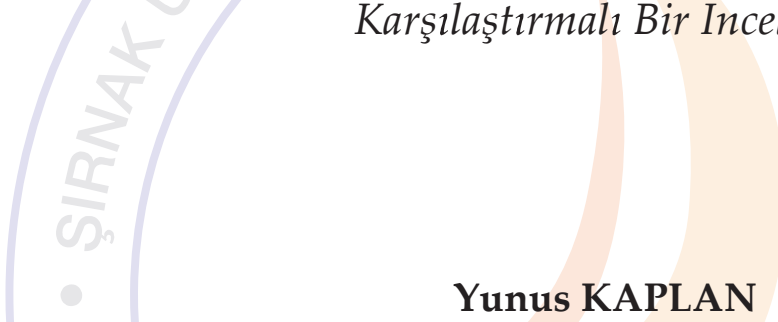

Dr. Öğr. Üyesi, Van Yüzüncü Yı1 Üniversitesi, İlahiyat Fakültesi, İslam Felsefesi Ana Bilim Dalı Assistant Professor Dr., Van Yüzüncü Yıl University, Faculty of Divinity, Department of İslamic Philosophy

Van, Turkey yunuskaplan@yyu.edu.tr https://orcid.org/0000-0002-7751-2309

\section{Makale Bilgisi / Article Information}

Makale Türü / Article Types: Araştırma Makalesi / Research Article

Geliş Tarihi / Received: 23 Ağustos / August 2019

Kabul Tarihi / Accepted: 9 Kasim / November 2019

Yayın Tarihi / Published: 15 Aralık / December 2019

Cilt / Volume: 10 Sayı / Issue: 23 Sayfa / Pages: 393-421

Atıf / Cite as: Kaplan, Yunus. "Ottoman Justice Thought in Tanzimat Period and Transitional Justice: A Comparative Analysis [Tanzimat Dönemi Osmanlı Adalet Düşüncesi ve Geçiş Dönemi Adaleti: Karşılaştırmalı Bir İnceleme]". Şırnak Üniversitesi Illahiyat Fakültesi Dergisi - Şırnak University Journal of Divinity Faculty 10/23 (December 2019): 393-421 https://doi.org/10.35415/sirnakifd.610131 Copyright $\odot$ Published by Şırnak Üniversitesi, İlahiyat Fakültesi / Şırnak, Türkiye (Şırnak University, Faculty of Divinity, Şırnak, 73000 Turkey). 


\begin{abstract}
One of the debates about contemporary political philosophy is related to historical perspective upon the Transitional Justice. This debate focuses on the probability of whether the historical perspective will in the Transitioal Justice practices. In addition to this, in the evaluations concerning Transitional Justice, recently happened events and implemented reforms are taken into account and historical examples are not frequently referred. In the present work, we will scrutinize the reforms made in American Reconstruction and Ottoman Tanzimat eras in terms of transitional justice. By taking both eras into consideration as two cases, we sought to question the possibility of historical perspective in the work. The work is limited to the legal arrangements and structural reforms in the considered eras. In the conclusion of the work, it is seen that the legal and structural reforms in both eras, which had the characteristics of transitional period, failed. In spite of this, it is probable to say that the taken steps related to justice formed the basis of many constitutional and legal reforms in the future. Additionally, these two cases demonstrate the significance of historical perspective in the studies of transitional justice.
\end{abstract}

Keywords: Philosophy, Islamic Philosophy, Ottoman Political Tought, Tanzimat Era, Transitional Justice

\title{
Öz
}

Siyaset felsefesi tartışmalarından biri de Geçiş Dönemi Adaleti'ne tarihsel perspektiften bakışla ilgilidir. Bu tartışma tarihsel perspektifle elde edilecek verilerin Geçiş Dönemi Adaleti uygulamalarında işe yarayıp yaramadığı noktasında odaklanmaktadır. Diğer bir tartışma konusu Geçiş Dönemi Adaleti ile ilgili değerlendirmelerde sadece yakın zamanda meydana gelen olayların ve reformların dikkate alınması ve tarihten örneklere çok sık müracaat edilmemesi ile ilgilidir. Bu çalışmada ABD'nin Yeniden Yapılanma Çağı'nda ve Osmanlı'nın Tanzimat Dönemi'nde gerçekleştirilen reformlar Geçiş Dönemi Adaleti açısından incelenmektedir. Makalede, her iki zaman dilimininde gerçekleşen reformlar örnek iki vaka olarak alınmakta ve Geçiş Dönemi Adaletine tarihsel perspektifle bakışın imkânı sorgulanmaktadır. Çalışma, esas alınan süreçteki yasal düzenlemeler ve yapısal reformlarla sınırlandırılmaktadır. İnceleme sonucunda her iki sürecin başarısızlıkla sonuçlandığı görülmektedir. Buna rağmen her iki dönemde atılan adaletle ilgili adımların ve reformların gelecekteki birçok anayasal ve yasal reformun zeminini teşkil ettiğini de söylemek mümkündür. Ayr1ca bu iki örnek geçiş dönemi adaleti incelemelerinde tarihsel perspektifin önemini ortaya koymaktadır.

Anahtar Kelimeler: Felsefe, İslam Felsefesi, Osmanlı Siyaset Düşüncesi, Tanzimat Dönemi, Geçiş Dönemi Adaleti 


\section{INTRODUCTION ${ }^{1}$}

It is plausible to delineate Transitional Justice as the justice formed in the process when societies sought to rid themselves of traumas appeared after the events of violence and conflict in which they became involved and built a fair future. This concept also means to take lessons from the past to establish infrastructure of the new regime installed in the process of transition from authoritarian to democratic regimes. Since the steps performed in this process are milestones of the prospective regime, democratic institutionalization is primarily intended with these steps. ${ }^{2}$

The notion of justice in the expression of transitional justice has a normative meaning and based on this concept, various spheres of legitimacy are formed. From this standpoint, societies that underwent weighty political transformations put a great number of judicial and administrative reforms into practice. The steps such as prosecution of criminals, elimination of fragmentations in the society, determination of victims and compensation of their loses, taking diverse steps so as to prevent occurrences of similar situations, and reforming administrative institutions are performed as a result of these reforms. Today, legitimacy is acquired through the fact that the concept of human rights is taken as a basis in the steps concerning transitional justice in order to compensate unjust treatments and that normative evaluations based on international law are made. ${ }^{3}$ In this respect, the legal responsibilities, which have to be undertaken by the states

1 This article is the product of my studies at Georgetown University, USA, where I worked as a researcher within the scope of TUBITAK 2219 Postdoctoral Research Fellowship between 2017-2018.

2 Serdar Gülener, "Çatışmacı Bir Geçmişten Uzlaşmacı Bir Geleceğe Geçişte Adalet Arayışı: Geçiş Dönemi Adaleti ve Mekanizmalarına Genel Bir Bakış", Uluslararası Hukuk ve Politika 8, 32 (2012): 44-45.

3 Pablo De Griff, “'Theorising Transitional Justice'”, in Transitional Justice, ed. Elster J, Nagy R, Williams M. (NewYork: NYU Press, 2012), 34-35. 
that carried out their reforms, are determined and these responsibilities constitute the basis of sanctions for violations of rights. Thanks to these bases, identification, prosecution and punishment of responsible persons are completed and thus taking different steps to prevent new violations are encouraged. ${ }^{4}$ Apart from these, the steps that are performed by any society in general terms at the end of conflicts and long term wars or at the time when the need to reform reached its highest level can be evaluated in this framework. ${ }^{5}$

By generalizing in their definitions of transitions period, Aoláin and Campbell state that the expression of the transition from authoritarian to democratic regimes is inadequate. According to this situation, as Serdar Gülener pointed out, the transition period in some types of transitional justice is also able to signify a transition to a more "peaceful and stable" model of democracy in relation to the type of democratic regime. Even if democratic values are adopted in these regimes, this situation can become apparent due to various ethnic, religious, class-based, and ideological discriminations or as a result of political tensions ${ }^{6}$ However, it is also possible to talk about transitional justice in the regime types in which the democratic model differs because of diverse reasons although some democratic developments take place.

Spheres of debate related to transitional justice, being a comparatively novel state in terms of political science and philosophy, are increasing by diversifying, and these debates offer diverse perspectives to the interrelated fields. One of the debatable areas is that transitional justice is a form of discourse. Here, the discourse created after September 11 in the context of the world order and international law are being criticized. According to this, transitional justice is setting an elitist language mostly based on the concept of international human rights. ${ }^{7}$

One of the spheres of discussion concerning political science concentrates on the complexity and fragility of processes. This complexity appeared in the process of reforms needed in the transition period can both

${ }^{4}$ Gülener, "Çatışmacı Bir Geçmişten Uzlaşmacı Bir Geleceğe Geçişte Adalet Arayışı: Geçiş Dönemi Adaleti ve Mekanizmalarına Genel Bir Bakış", 46.

5 Jeremy Webber, "Forms of Transitional Justice", Nomos 51 (2012): 98-99.

6 Fionnuala Ní Aoláin - Colm Campbell, "The Paradox of Transition in Conflicted Democracies", Human Rights Quarterly, 2005, 172-213.

7 For other areas of debates related to transitional justice, see: Roger Duthie, "Transitional Justice and Displacement", International Journal of Transitional Justice 5/2 (2011): 241-261.; A. James McAdams, "Transitional Justice: The Issue That Won't Go Away", International Journal of Transitional Justice 5/2 (2011): 304-312. 
offer new opportunities for and constitute different impediments to the prospective determinants. ${ }^{8}$ Additionally, the issue of the shortcomings in the judicial system in the case of judgments concerning the past and how judgments will be sustained is another subject of discussion in this context. In some cases, the high numbers of persons committing crime or huge number of victims make processes of court difficult, and the lack of the relevant constitutional articles and legal regulations makes this process more difficult. In addition to these, various amnesties and constitutional limitations, authoritarian gaps in the new regimes etc. create other fields of technical debates. ${ }^{9}$

Teitel mentions that constitutions and normative claims in the transition process make a transition to a more liberal order probable owing to an official historical anxiety. According to Teitel, the fact that historical understanding is based on political and social facts must be accepted. By expressing that what history constitutes in the transitional periods depends not only on the historical and political legacies of regions but also on the context proper to the transition, Teitel indicates that the shape of the transitional dates, idealized as bases, ignores pre-historical experience. From his viewpoint, the historical experiences gained in the transitional periods are not certainly autonomous and can only be understood in their relation to predetermined national narratives. The past of ongoing collective memory can only define a society. Thus, the fact of transition is socially constructed in the processes of collective memory. When social practices are revealed in these periods, historical experiences are infrequently taken into consideration. Finally, the history of transitional periods inspires us about how determined legal norms and practices produce historical conclusions and facts and about the role of history in political liberation. ${ }^{10}$

Another debate mainly held in the field of political philosophy is connected to the possibility of looking at historical cases from a historical perspective. The basic idea of this field of debate, which is called attention and contributed to by Jon Elster in his book, Closing the Books: Transitional Justice in Historical Perspective, is that transitional justice can be viewed from a

8 Cath Collins, Post-transitional Justice: Human Rights Trials in Chile and El Salvador (Penn State Press, 2010), 13-14. See also: Thomas Obel Hansen, “Transitional Justice: Toward a Differentiated Theory", Or. Rev. Int'l L. 13 (2011): 1.

9 Gülener, "Çatışmacı Bir Geçmişten Uzlaşmacı Bir Geleceğe Geçişte Adalet Arayışı: Geçiş Dönemi Adaleti ve Mekanizmalarına Genel Bir Bakış", 46. See also: Hansen, "Transitional Justice: Toward a Differentiated Theory".

${ }^{10}$ Ruti G. Teitel, Transitional Justice (Oxford University Press, 2000), 69-73. 
historical perspective. While expressing this claim, Elster considers the reform steps performed in the city-state of Athens between 403 and 4011 B.C. and the restoration processes taking place in France between 1814 and 1815 as two sample cases and then makes evaluations concerning transitional justice on both cases. In his book, Elster scrutinize how the past governments coped with the problems of transition period. In addition, he evaluates possibilities and limitations of transitional justice and examines why transitional justice acquired diverse forms in different historical eras. He also emphasizes that it is not requisite for him to make recommendations to the countries in transition period, to offer a theoretical framework concerning transitional justice or to participate into the debates held by theoreticians. Elster says that what he did is composed of offering a perspective and material for philosophers, historians, jurists, and political scientists by providing examples from history. Elster, describing Transitional Justice as a form of justice appeared at the transition from one regime to other, comes to the conclusion that the problems arising from the transition from autocratic administrations to liberal democracies are the same to the problems emerged in the transition from the old to new regimes. In his book, he states that he discovered "the context-dependence of the phenomena to be an insuperable obstacle to generalizations". As Elster highlights, even if this study presents us a typology for variations of transitional justices in time and space, it does not bring us near a "law" of transitional justice. ${ }^{11}$

As being in Elster's approach, is it possible to look at other cases within a historical perspective? Can different cases of justice experienced in the past be scrutinized? What does such a study mean in terms of transfer of justice from theory into practice and in terms of transitional justice? Based on these questions, the main purpose of this work is to make a case study on the Ottoman and American samples in the context of transitional justice. Firstly, in line with this purpose, the reforms carried out by both states in the selected historical processes in the name of justice will be analyzed. Secondly, because of the relation of the subject to political philosophy, the philosophical bases of both states and the intellectual background of the steps taken will be examined.

The subject will be analyzed by being limited with the transitions processes, which are marked as the turning points lived by both countries in the half of the $19^{\text {th }}$ century. Here, the concrete steps performed, namely the

${ }^{11}$ Jon Elster, Closing the Books: Transitional Justice in Historical Perspective (Cambridge University Press, 2004), 77. 
nature of legislation and reforms, will be evaluated and the manifestation in the historical process will be presented. Furthermore, by concentrating on the Ottoman political thought, the subject will be limited in terms of time because of its wideness. The US Reconstruction Era (1863-1877) and the Ottoman Tanzimat Period (1839-1878) will be taken into account in the work for the reason that time limit of the current comparison is determined according to possibility of acquiring data and conformity between elements of comparison. The reasons of why these two eras have been preferred are that both periods portrayed the transitional character after deep trauma, some legal and administrative reforms were implemented in these eras, and these reforms constituted the basis of following reforms.

There are some criteria to determine the period of a research. The first of these criteria is the reforms and applications of justice made by both states, the steps taken because of increasing demands for administrative reforms, and the attempt to overcome ongoing legal problems. The second is the possibility of accessing to data of the implementations of the periods. In this respect, there are sufficient sources to make a comparison possible between two samples. It is a fact that both cases have not been compared until today and a sufficient literature has not already been formed. ${ }^{12}$ It is necessary to place some limitations to the research. The basic limitation is related to the legislative activities and the reforms of administrative organizations originated in both states' thoughts of justice. The issue will be analyzed without transcending these limitations. By paying attention to this point, the legislative, executive, and judicial systems will not widely examined but they will be considered in the context of their relations to the subject. In addition, such an examination is crucial in terms of the history of the Ottoman thought. It is apparent that examining experiences lived in history and testing the outcomes of these experiences as two sample cases will contribute to the current debates concerning transitional justice. On the other hand, the fact that the Ottoman and the US societies, both shared common characteristics and had sharp differences, had historical experiences and made efforts to overcome problems of the transition periods will offer an opportunity to understand histories of thoughts of both states properly and to gain data for current political philosophies.

${ }^{12}$ For the comparative studies conducted on the different subjects between the Ottoman Empire and the USA, see: Gürsu Galip Gürsakal, "Osmanlı ve Büyük Güçlerin Askeri Harcamalarına Karşılaştırmalı Bir Bakış (1840-1900)”, Gazi Akademik Bakış 4/7 (2010): 115-131. 


\section{THE USA IN THE RECONSTRUCTION ERA}

We will scrutinize The Reconstruction Era (1863-1877) in the context of the transitional justice started at the time of the US civil war (1861-1865) and continued until the year of 1877. It was a period composed of legal, political, and economic arrangements in the structure of the state and society. Many reforms related to justice and inspiring the prospective reforms of the USA society were put into practice in this process. Some of these reform contained constitutional and legal activities while some of them were related to a number of different practices. The Freedmen Office's endeavor to cope with the aftermaths of the war, steps of education and schooling were some of these practices. Although this process was short and unsuccessful, it formed the basis of the prospective reforms of the US society and had characteristics of the transition process. This is why we considered the process as a case in our work. Under this title, after touching on the basic problems concerning justice in the reconstruction era, enactment activities, and the rights gained, we will discuss the activities of the Freedmen Office.

The Reconstruction Era refers to the attempts to coping with the problems related to the construction of the American national unity, the role of government in protecting the rights of citizenship, economic and social equality, elimination of racism and discrimination, and providing justice. In this context, the fundamental factors preparing the era of the transition period were civil war, economic and political aftermaths of this war, and debates of citizenship. In order to overcome these problems in the provinces of the Confederate States of America, different legal arrangements were made, some organizations were reviewed, and new organizations were established. At the same time, "civil rights law" was declared, many legal arrangements related to slavery were made, and crucial implementations concerning justice were put into practice. Additionally, this was a period on which both black and white people work for democracy. However, the process took a short time due to its mismanagement, economic problems, corruption, and violence and discrimination. In short, this policy lasted until 1877 even if the reconstruction started at different times in every province. $^{13}$

\section{TRANSITION PROCESS AND ENACTMENT ACTIVITIES}

The most significant step concerning transitional justice in the Recon-

${ }_{13}$ Orville Vernon Burton, the Age of Lincoln: A History (Hill and Wang, 2008). 
struction Era was the formation of legal frames and structural reforms. On September 22, 1862, the Preliminary Emancipation Proclamation was declared at the time of the Civil War. After this proclamation, the first concrete step in the annulment of slavery, the other step was the Emancipation Proclamation was announced on January 1, 1863. The liberation of more than three million slaves was covenanted with this proclamation. ${ }^{14}$ The proclamation was a crucial milestone even if it was not enough totally to abolish slavery.

The first crucial enactment activity related to justice was Civil Rights Act of 1866 after the war. This Act, coming into force on April 9, 1866, was the first law of the United States that defined citizenship and warranted that all citizens would be equally protected by laws. ${ }^{15}$ This law was enacted to protect the rights of those born in or brought to the USA after the Civil War. The bill was approved in April 1866. ${ }^{16}$ With this law, it was accepted that all persons born in the USA and those who were not subject to any foreign country were citizens without consideration of their race, color, previous slavery or involuntary slavery. It was also accepted that every citizen had all kinds of rights such as contracting, filing a lawsuit, offering evidence in court and inheriting, selling, renting etc. All citizens' lives, properties, and property rights were secured. Further, this law was approved as one of the bases of the federal government policies in the Reconstruction Era. President Andrew Johnson announced some significant legal reform plans concerning reconstruction at the end of 1865. These plans were accepted with the name of Reconstruction Laws. ${ }^{17}$ Thus, the right to vote and to take office in the state was given to the southern blacks.

It is seen that some negative legal steps were taken in this period. One of these was the laws known as Black Codes. These codes were enacted by the Southern States to restrict the liberties of Afro-Americans and to compel them to work in a low-waged or debt-based labor economy between 1865 and 1866. Before the Civil War, the Northern States such as Illinois, Indiana, Michigan and New York put the Black Codes into practice to for-

${ }^{14}$ Richard Striner, Father Abraham: Lincoln's Relentless Struggle to End Slavery (Oxford University Press, 2007), 176; Louis P. Masur, Lincoln's Hundred Days: The Emancipation Proclamation and the War for the Union (Harvard University Press, 2012).

${ }^{15}$ Salzman, Lawrence, "Civil Rights Act of 1866", in Encyclopedia of American Civil Liberties, ed. Paul Finkelman, v. 1 (CRC Press, 2006), 299-300.

${ }^{16}$ Michael W. Fitzgerald, Splendid Failure: Postwar Reconstruction in the American South (Ivan R Dee, 2007).

17 Albert E. Castel, "Andrew Johnson", The Presidents: A Reference History, ed. Henry Franklin Graff, 7. Bs (New York-USA: Charles Scribner's Sons : Thomson/Gale, 2002), 225-239. 
bid liberated blacks to live within their borders. The Southern States also accepted this prohibition between 1865 and 1866. Johnson, supporting the annulment of slavery, also accepted that the Southern States were free to reconstruct them providing that they would be subject to the union and pay the war debt. Because of Johnson's attitude, many southern states in 1865 and 1866 put these codes into practice to restrict the emancipated blacks' activities and re-employ them as workers. These codes were like a kind of legal shield formed against the slaves having a great significance in economy as a work force. Actually, they were enacted to prohibit the unliberated slaves from liberating and to deprive the liberated slaves of some rights. They were also intended for reducing the potential impacts of the liberated blacks (specifically after the slave uprisings) on other slaves. These codes imposed restrictions on the blacks' rights to vote, to carry weapon, to pray, and to come together to read and write. ${ }^{18}$

One of the most significant steps forming legal frame in the Reconstruction Era was the $13^{\text {th }}, 14^{\text {th }}$ and $15^{\text {th }}$ constitutional amendments. The last change in the Constitution had been made in 1804, namely more than 60 years ago. The slavery and compulsory slavery were abolished with the $13^{\text {th }}$ amendment excepting those slaves sentenced in conformity with the laws. Citizenship and concept of legal equality were redefined with the $14^{\text {th }}$ change. With the $15^{\text {th }}$ amendment, all citizens were accepted to have the right to vote without discriminating race, color, or slavery. ${ }^{19}$

\section{A NEW HOPE: SOME RIGHTS GAINED}

The most important achievement of the Reconstruction Era was that it raised hopes of people. This era was significant particularly for the emancipated slaves because it was a source of hope for them. In the past, that the slaves gained the rights to be able to vote and to have estates and the blacks could travel on the same train with the whites in some states and to eat with them at the same restaurant could be accepted as huge changes in respect of dressing the social wounds. In this process, that schools and orphanages were constructed to make lives of the blacks living in the south easy and aid projects were run aroused the hopes for the future. However, the most

${ }^{18}$ Joseph A. Ranney, in the Wake of Slavery: Civil War, Civil Rights, and the Reconstruction of Southern Law (Greenwood Publishing Group, 2006).

19 The 19th amendment made in 1920 contained the arrangements concerning gender discrimination because these changes did not contain any expression related to this discrimination. This article gave the right to vote to every woman and man, having estates without race division and some characteristics, in the states such as New Jersey. 
influential reforms in this process were that the black could shoulder political tasks. According to this, the blacks could henceforth be sheriffs and judges. Furthermore, that the blacks could be elected to school unions and city councils and 16 blacks had seats in the Congress between 1867 and 1877 was the significant step in terms of the transitional justice. That Hiram Rhodes Revels was elected as the first Afro-American senator of Mississippi in 1870 was important in respect of the political aspect of the steps performed. Additionally, that P.B.S. Pinchback was appointed the first Afro-American governor of Louisiana in December 1872 and approximately 600 black citizens had official duties in the states was among the important political steps. That the liberated slaves in the southern states, the whites coming from the north (Carpetbagger) and the poor white southerners (Scalawag) playing role in forming republican governments was also among the mentioned crucial steps. ${ }^{20}$ The fact that these governments took part in the significant activities such as restructuring the region, developing railways, and opening state schools played a crucial role in putting laws from theory into practice.

Other accomplishments, making the period valuable on the subject of transitional justice, as we have already mentioned, were related to slavery and citizenship. As being known, slavery, having not only legal but also economic dimensions, was an area of socio-political problem. Therefore, the decisions concerning slavery had the dimensions making constitutional amendments compulsory. Besides these structural reforms, the practical steps such as preventing extremities, providing social integration, supporting and completing educational processes, and performing audits and supervisions had to be taken.

Lincoln prepared an action plan in 1861 before the Reconstruction Era during the Civil War and offered the bill of Compensated Emancipation concerning slavery to the Congress. ${ }^{21}$ According to this, the condition of compensation to emancipate from slavery still ongoing in some states was accepted. ${ }^{22}$

${ }^{20}$ Michael Perman, The Road to Redemption: Southern Politics, 1869-1879 (Univ of North Carolina Press, 1985). For more details see, Peter Kolchin, "Scalawags, Carpetbaggers, and Reconstruction: A Quantitative Look at Southern Congressional Politics, 1868-1872", The Journal of Southern History 45/1 (1979): 63-76.; Walter Lynwood Fleming, Documentary History of Reconstruction, Political, Military, Social, Religious, Educational \& Industrial, 1865 to the Present Time (AH Clark Comany, 1907).

${ }^{21}$ William MacDonald, Select Charters and Other Documents Illustrative of American History, 16061775 (Macmillan, 1910), 35; Junius P. Rodriguez, Slavery in the United States: A Social, Political, and Historical Encyclopedia (Abc-clio, 2007), 1: 238-239.

${ }^{22}$ Kevin Bales, Buying Freedom: the Ethics and Economics of Slave Redemption (Princeton University Press, 2007). 
Thus, slaves would be able to emancipate by paying money or working for a while. However, when this proposal was supported, Lincoln ratified the District of Columbia Compensated Emancipation Act on 16 April 1862.. ${ }^{23}$ The slavery in the region was prohibited and some laves were released with this act. Lincoln also supported extension of the right to vote for the educated blacks and former soldiers. That Lincoln accepted the Federal Homestead Law $^{24}$ on May 20, 1862 and proclaimed the Pre-Independence Declaration on September 22 was some steps of justice strengthening the process. ${ }^{25}$ Lincoln also endeavored to abolish slavery in some states seized by the Northerners. This was the purpose of why the slaves released in the states of Tennessee, Arkansas, Louisiana and South Carolina were given the lands taken from the white landowners.

Finally, in this process, some steps that made the transition era special were the laws (including assistance to railways and other businesses) against the racial discrimination in the areas of fair taxation, public transportation and accommodations, and implementation of economic development programs. In addition, the political and civic liberties including the right to vote and equal protection, gained by the black Americans and slaves thanks to the constitutional amendments, were among these steps. It may even be stated that annulment of slavery and constitutional assurance were significant steps all on their own.

\section{FREEDMEN BUREAU AND PRACTICAL JUSTICE}

The most concrete steps in the Reconstruction Era in the name of justice were the actions of the Freedmen Bureau. The operations of the Bureau aroused the hopes that this process would be concluded successfully. The officials of the Bureau, seeking to solve the daily questions of the recently released slaves such as clothing, food, water, health, communicating with the family members and finding work, undertook the tasks of the legal lawyer for the Afro-Americans both at local and national courts especially in the cases concerning family matters. The Bureau tried to make the largest lands cultivate and called the liberated slaves to turn back to their works. In

${ }^{23}$ Rodriguez, Slavery in the United States: A Social, Political, and Historical Encyclopedia; Peter Zavodnyik, The Rise of the Federal Colossus: The Growth of Federal Power from Lincoln to FDR: The Growth of Federal Power from Lincoln to FDR (ABC-CLIO, 2011).

${ }^{24}$ Melvin Oliver - Thomas Shapiro, Black Wealth/White Wealth: A New Perspective on Racial Inequality (Routledge, 2013), 14-15.

${ }^{25}$ Eric Foner, Free Labor, Free Soil, Free Men: The Ideology of the Republican Party before the Civil War (New York: Oxford University Press, 1970). 
this period, by following the processes, it also made the contracts between the new free laborers and the landowners. ${ }^{26}$ The attempts of the Bureau in the subject of health, one of the most crucial problem areas of the era, remained insufficient. Doctors and nurses, mostly white southerners, did not treat patients. The infrastructure problems created by the war continued. Additionally, the blacks were not allowed to train their own medical staff. Cholera epidemics, yellow fever and typhus were several of the most common diseases. ${ }^{27}$

The black women emancipated in the reconstruction era rejected to take part in employment contract, working and entering into the labor market. The Bureau attempted to make these women with their husbands a part of the labor force in the cotton industry. With the attempts of the Bureau, some privileges were granted for the wives of workers, widows, left women, and the large family women obliged to look after small children. ${ }^{28}$ In this period, the Bureau sought to help those who wanted to prevent informal marriages and to marry. It pioneered in uniting the separated families and undertook the duty of communicating between the families members that lost each other during the war. ${ }^{29}$ Even the free women who wanted to divorce could apply to the Bureau. The informal marriages increased in the war process and this circumstance led to big problems particularly for slaves. The Bureau also tried to produce solutions to the problems such as marriage and divorce. ${ }^{30}$ Liberated Afro- Americans and poor whites received food aid worth of 5 million dollars and pregnancy aid worth of 15 million dollars between 1865 and 1869. A credit system was established for necessary provisions to feed the self-employed persons who employed workers in the fields. 350 thousand dollars were devoted to this service. ${ }^{31}$ However, in spite

${ }^{26}$ Robert C. Lieberman, "The Freedmen's Bureau and the Politics of İnstitutional Structure", Social Science History 18/3 (1994): 407.

${ }^{27}$ Jim Downs, Sick from Freedom: African-American Illness and Suffering during the Civil War and Reconstruction (Oxford University Press, 2012), 65-67.

${ }^{28}$ Richard Fleischman and oth. "The US Freedmen's Bureau in post-Civil War reconstruction", Accounting Historians Journal 41/2 (2014): 85-86.

${ }^{29}$ Fleischman and oth., "The US Freedmen's Bureau in post-Civil War reconstruction", 101; see also Lara Vapnek, the Politics of Women's Work in the United States, 1865-1909 (Columbia University, 2000).

${ }^{30}$ Mary Farmer-Kaiser, Freedwomen and the Freedmen's Bureau: Race, Gender, and Public Policy in the Age of Emancipation (Fordham Univ Press, 2010), 14-27.

${ }^{31}$ Robert Harrison, "New Representations of a 'Misrepresented Bureau': Reflections on Recent Scholarship on the Freedmen's Bureau", American Nineteenth Century History 8/2 (2007): 210-212; For a statistical statement, see, Lieberman, "The Freedmen's Bureau and the Politics of İnstitutional Structure", 416-417 See also, Congressional Globe, 40th Congress, 2nd Session (hereafter cited in the form CG, 40.2): 1814; Report of the Commissioner 
of all good purposes and efforts, accomplishment remained limited and the problems of the emancipated slaves continued to exist.

\section{THE END OF THE RECONSTRUCTION ERA}

The Reconstruction Era is one of the most essential turning points in the history of the US civil rights. This era ended unsuccessfully according to numerous researchers in spite of the annulment of slavery, gaining in civil rights, some gained rights concerning property, and the steps related to public duty and political participation. We can state that the end of the Reconstruction Era started in 1874 and completed in 1877. The economic crisis arisen in 1874 made the South poorer. Infrastructure constructions almost stopped. The Democratic Party got control of the House of Representatives for the first time since the Civil War. Racism and violence augmented both in the south and in the north, and the federal government was not directly getting involved in these events. The Republican states were slowly altering their policies and losing their powers in the House. Ulysses S. Grant rejected to send a federal unit against the violence campaign started by the Democrats in Mississippi in 1875. He also menaced to cease federal support for the Reconstruction administrations in the South. The whites did not accept the emancipated blacks to have the right to vote and the egalitarian policies followed by the governments. This attitude became gradually prevalent and at the end of the day, violence became the biggest impact on ending the period. Numerous liberated slaves still did not know how to read and write. Job opportunities were restricted. These slaves could only do farming and use hand labor, and did not technically know how to do the farming. This situation made them the worker slaves of the farmers. Their monies, clothes and shelters were also limited. Most of the slaves became the partners of the landowners in the lands in place of their labors but landowners could not pay their salaries. In conclusion, the White Southerners excluded others by means of violence, oppression and racism and kept them out of politics. ${ }^{32}$

of the Bureau of Refugees, Freedmen and Abandoned Lands for the Year 1867 (Washington, 1867), 5-39; Paul Alan Cimbala - Randall M. Miller, The Freedmen's Bureau and Reconstruction: Reconsiderations (Fordham Univ Press, 1999), 4: 40-47; Reggie L. Pearson, “"There Are Many Sick, Feeble, and Suffering Freedmen": The Freedmen's Bureau's Health-Care Activities during Reconstruction in North Carolina, 1865-1868", The North Carolina Historical Review 79/2 (2002): 141-181.

${ }^{32}$ Nicolas Barreyre, "The Politics of Economic Crises: The Panic of 1873, the End of Reconstruction, and the Realignment of American Politics", The Journal of the Gilded Age and Progressive Era 10/4 (2011): 403-423. 
Consequently, the Democrats took control of the whole South except Florida, Louisiana and South Carolina. In the election campaign, Republican candidate Rutherford B. Hayes pledged control of the whole South to the Democrats in the Congress in place of acceptance of his election. Black Codes were enacted in the Southern states to take control of or reimplement the old social structure. The Southern states enacted some laws limiting the citizenship rights of the former emancipated slaves. Some states even abolished the right of women to vote. The whites who were still powerful compelled the free slaves to obey to the rigid laws known as the Black Codes. In the South Carolina, blacks were obliged to pay a special tax if they were not farmers or servants. In some regions, the blacks were not allowed even to hunt or fish. The blacks had no right to arm and even those having a dog had to pay tax. Orphanages, parks, schools and other public facilities were also prohibited for them. The Freedmen Bureau, a federal institution established to manage the process of transition from slavery to freedom, was blocked to take steps for the prosperity of the newly liberated slaves. These steps compelled the majority of the free slave to re-work at farms and farming lands. Jim Crow laws were applied to limit the rights of Afro-Americans in some states after 1876. By 1877, the Southern Democrats started a campaign against the reconstruction policies containing severe measures against racism. This was the final point at the end of the Reconstruction Era.

\section{THE WAY TO TANZIMAT REFORMS}

One of the most significant turning points regarding both the Ottoman political thought and the idea of justice is undeniably the reforms of the Tanzimat Period, stamped on the second half of the $19^{\text {th }}$ century. ${ }^{33}$ It is possible to say that an era of improvement similar to the process of improvement experienced in the US Reconstruction Era took place in the Ottoman Empire approximately in the same period. Although both processes developed depending on different political and social factors, it is observed that the suitable outcomes that could be evaluated in accordance with the transitional justice were produced in both processes.

The degenerations in the state and social structures of the Ottoman Empire that strained to keep pace with the political and social changes in the West, the increasing pressure of the strengthening West, the common needs of the society, and the apparent injustices in the political and legal

33 İlber Ortaylı, İmparatorluğun En Uzun Yüzyılı (İstanbul: Timaş Yayınları, 2008). 
fields forced the Ottoman political and legal system to change. ${ }^{34}$ In order to provide solutions, the idea that existing laws had to be revised and new laws had to be enacted in place of the laws representing the thought of classical justice, and administrative, financial and judicial reforms had to be implemented started to be widely accepted. In the Tanzimat Era, numerous reforms were performed, various laws were enacted, and the structures of political, judicial and legal organizations were transformed. At the end of the day, these performed steps took their place in the history as milestones for a regime change..$^{35}$

If we consider the process leading to the Tanzimat reforms, we can say that the origins of these reforms started to constitute beginning from the $18^{\text {th }}$ century. The main objective of the reforms stamped on the second half of the $18^{\text {th }}$ century, especially Selim III (1789-1807) and Mahmut II (1808-1839) periods was not to be far behind the industrializing Europe. The reforms realized in agreement with this aim were mostly related to military and political issues. ${ }^{36}$ Unlike the previous reforms performed, the reforms of the Tanzimat Era were based on the idea of reviving the empire on new grounds. These reforms comprised the idea of a new Europeanstyle state model. The pledged rights, the targets of administrative, financial and military measures in the Tanzimat Edict were shaped in conformity with Western models. ${ }^{37}$ In the name of regarding justice, Muslims and non-Muslims, all Ottoman subjects, were promised to have these rights. However, the idea of equality in the Western sense was heavily stressed as opposed to the Shari 'a, the basis of the Ottoman law. This was why justice and equality became the strongest slogan of the Tanzimat reforms. Ideally, welfare and contentment of all subjects regardless of their religions and nationalities were taken into account. ${ }^{38}$ It was believed that the idea of justice and equality would unite all the subjects and ensure the survival of the empire. ${ }^{39}$

${ }^{34}$ Dora Glidewell Nadolski, "Ottoman and Secular Civil Law" International Journal of Middle East Studies 8/4 (1977): 517-543.

${ }^{35}$ M. Şükrü Hanioğlu, A Brief History of the Late Ottoman Empire (Princeton, NJ: Princeton University Press, 2010).

${ }^{36}$ Niyazi Berkes, The Development of Secularism in Turkey (Montreal [Québec]: McGill-Queen's Press-MQUP, 1964).

${ }^{37}$ Shirine Hamadeh, "Ottoman Expressions of Early Modernity and the «Inevitable" Question of Westernization," Journal of the Society of Architectural Historians 63/1 (2004): 32-51.

${ }^{38}$ In the 1840 dated criminal regulations, this issue was stated as follow: "ber-muktezay-1 hürriyet-i şer'iyye huzur-1 şer' ve kanunda ve mevadd-1 hukukiyede herkesin yeksan ve seyyan olması umur-1 tabiiyyeden...".

${ }^{39}$ Hamiyet Sezer Feyzioğlu - Selda Kılı̨̧, "Tanzimat Arifesinde Kadılık-Naiplik Kurumu", 
The legal system and the questions concerning judicial organizations in the process leading to Tanzimat reforms, especially spread of bribery and favoritism and increasing number of unqualified kadis and regents were the most significant factors devastating justice. This was why enactments and reforms of legal organization contained the steps mostly related to transitional justice. ${ }^{40}$ In conclusion, the rebellions of diverse ethnic groups and the Ottoman non-Muslims subjects, the lost wars and economic problems, and the pressure of justice and powerful states raised the need for a new reform grounded on the concept of equality to the highest level. ${ }^{41}$

The enactments of the Tanzimat Era were put into practice in order to reach the general targets stated in the Tanzimat and Islahat edicts. However, activities of enactments were the results of needing practical justice. ${ }^{42}$ The first reason of these enactments was the internal questions accumulated for more than 150 years as also stated in the edicts. The second reason was external interferences. Most of both internal and external problems were related to justice. This was the basic reason of why the Tanzimat regulations gave great importance to the justice. The steps taken and the legal regulations were to overcome these issues. In other words, the edicts in which the reform goals were stated formed the basis of the enactments. The insufficiency of the reforms of the Tanzimat Era, mostly premeditated as transitional steps, led to emergence of the need for regime change. ${ }^{43} \mathrm{It}$ is probable to evaluate the proclamation of the Ottoman Constitution of 1876 (Kanun-i Esasi) and the constitutional monarchy as the result of this need.

\section{THE FIRST STEPS OF TRANSITION PERIOD: THEORIES}

The most significant and first pillar of the transition process in the Tanzimat Era was the Tanzimat Edict. ${ }^{44}$ This edict was similar to the justice decrees (adaletnâmes) proclaimed by the previous sultans but it was different be-

Ankara Üniversitesi Dil ve Tarih-Coğrafya Fakültesi Tarih Bölümü Tarih Araştırmaları Dergisi 24/38 (2005): 31-53.

${ }^{40}$ Jun Akiba, "Kadılık Teşkilatında Tanzimat'ın Uygulanması: 1840 Tarihli Ta'limname-i Hükkam," Osmanlı Araştırmaları 29 (2007): 11.

${ }^{41}$ Ali Akyıldız, Osmanlı Bürokrasisi ve Modernleşme (İstanbul: İletişim Yayınları, 2004), 84-85.

${ }^{42}$ Ali Akyıldız, "Tanzimat", Türkiye Diyanet Vakfı İslam Ansiklopedisi (İstanbul: TDV Yayınları, 2011), 40: 1-2.

${ }^{43}$ Bülent Tanör, "Anayasal Gelişmelere Toplu Bir Bakış", Tanzimat'tan Cumhuriyet'e Türkiye Ansiklopedisi 1 (1985): 13.

${ }^{44}$ Butrus Abu-Manneh, "The Islamic Roots of the Gülhane Rescript", Die Welt des Islams 34/2 (1994): 173-203. 
cause it included fundamental changes in the sense of political thought. ${ }^{45}$ The chief determined purpose of the Edict was to take and implement decisions to keep the peoples intending to separate from the Ottoman Empire under the influence of nationalism under the roof of Ottomanism. The Edict also revealed the conviction that the present state structure became the source of the problem and that the idea of justice lost its influence. ${ }^{46}$ It is probable to evaluate this Edict, proclaimed because of the conviction of higher officials, as the effort of accepting the mistakes made and facing the facts. The following steps taken and edicts issued were the continuum of this first step.

The most significant matter in the sense of justice in the text of the Tanzimat Edict was the emphasis on the law. In the text, it was expressed that "the rules of the Qur'an and the laws of the Shari'a had been obeyed" since the establishment of the state until the last 150 years. This was the restatement of the fact that the basis of the law in the state was Islamic Jurisprudence (fikıh) and that this idea was not abandoned. ${ }^{47}$ The emphasis in the Edict that the downward trend had continued for 150 years indicated the present mental background about the source of problems. According to this, the problems concerning development, public security and welfare were originated in the disobedience to the rules of law. Besides, according to the articles offering solutions, most of the problems were related to justice. ${ }^{48}$ The solution was to enact new laws. The judgments on life safety, chastity and honor, protection of property, principles of taxation, and military service and its duration constituted the key elements of these laws. ${ }^{49}$

The fact that the commitments on the equality given in the Tanzimat Edict were not subsequently fulfilled produced wide public pressure. Further, non-Muslim subjects attempted to put pressure on the government by expressing their demands. These pressures panned out and the Islahat

${ }^{45}$ Murteza Bedir, "Fikih to Law: Secularization Through Curriculum," Islamic Law and Society 11/3 (2004): 381.

${ }^{46}$ Gürsoy Akça - Himmet Hülür, "Tanzimattan Cumhuriyete Siyasal ve Hukuksal Yapının Modernleşmesi", Selçuk Üniversitesi Türkiyat Araştırmaları Dergisi, 21 (2007): 244-245.

${ }^{47}$ M. Akif Aydın, "Kanunnameler ve Osmanlı Hukuku'nun İşleyiş̧indeki Yeri", Osmanlı Araştırmaları 24/24 (2004): 40.

${ }^{48}$ Bülent Tahiroğlu, "Tanzimat'tan Sonra Kanunlaştırma Hareketleri", Tanzimat'tan Cumhuriyet'e Türkiye Ansiklopedisi 3 (1985): 588-589.

${ }^{99}$ The statements in the Edict are as follow: “...bundan böyle Devlet-i Aliye ve Memâlik-i Mahrûsemiz'in hüsn-i idâresi zımnında bazı kavânîn-i cedîde vaz' ve te'sîsi lâzım ü mühim görünerek işbu kavânîn-i mukteziyyenin mevâdd-1 esâsiyyesi dahi emniyet-i can ve mahfûziyyet-i irz u nâmûs u mal ve tayîn-i vergi ve asâkir-i mukteziyyenin sûret-i celb ve müddet-i istihdâmı kazıyyelerinden ibâret olup şöyle ki..." 
Edict was declared in $1856 .{ }^{50}$ In the introduction of the Edict, the demand of ensuring the permanence of the arrangements made until now and extending these arrangements to promote the state's position at the international level was expressed. Thus, both the state would be fortified and the citizens' allegiances would increase. ${ }^{51}$ In addition to the regulations about the general wants of Ottoman subjects, it is probable to state that the needs of non-Muslims were also considered in the Edict.

The large segments of the society, especially the Muslim subjects, did not welcome these commitments made in the Edict in a theoretical manner and even in some regions it was complained that these commitment were not put into practice. ${ }^{52}$ Because of these complaints, the foreign states sent a memorandum concerning the subject to the Ottoman state in 1859. An inspection committee was sent to the Rumelian districts due to this. However, the inspector reports did not resolve the complaints. Although justice and reform were promised in relation to the subject, these steps did not overcome the objections. The fact that the Tanzimat Edict established equality not only between the Christian sects but also between the Muslims and non-Muslim bothered the Orthodox subjects, more powerful and privileged than the other sects. In the outside world, the United Kingdom and France appreciated the Tanzimat while Russia disapproved of the Edict by thinking that this would increase the Western impact on the Ottoman state. While Prince Metternich, adherent of absolutism in power in Austria, welcomed the Edict, Kavalalı Mehmet Ali Pasha maintained that the goal of the edict was to undermine his authority. The New Ottomans in the era of Sultan Abdulaziz objected to some applications of the Tanzimat and lots of them were banished or obliged to escape to abroad.

\section{LEGISLATIVE ACTIVITIES AND PRACTICES}

The enactment activities that meant the implementation of the targets mentioned in the Tanzimat and Islahat Edicts and legislative processes and that offered concrete data in the sense of transitional justice were the most crucial pillar about the practice of the thought of justice of the Tanzimat Era. ${ }^{53}$ The enactments of the Tanzimat Era had noteworthy features regard-

${ }^{50}$ For detailed information concerning Islahat Edict, see: Ufuk Gülsoy, "Islahat Ferman1", Türkiye Diyanet Vakfı İslam Ansiklopedisi (İstanbul: TDV Yayınları, 1999).

${ }^{51}$ Musa Gümüş, “Anayasal Meşrûtî Yönetime Medhal: 1856 Islahat Fermanı'nın Tam Metin İncelemesi", Türk Dünyası Sosyal Bilimler Dergisi 47 (2008): 215-240.

${ }^{52}$ Kasım Ertaş, Osmanlı Imparatorluğu'nda Diyarbakır Ermenileri (İstanbul: Rağbet, 2015), 130.

53 Bedri Gencer, "Son Osmanlı Düşüncesinde Adalet”, Muhafazakâr Düşünce Dergisi, 15 (2008): 123-147. 
ing the transitional justice because they contained the legal regulations related to the issues stated in the Tanzimat Edict. ${ }^{54}$ Above all, they were the most concrete strides indicating the Ottoman attempts for reformation, modernization and reform. ${ }^{55}$ In addition to the enactments, the other concrete outcome of the reform volition was the reforms in the organizations. The most significant organizational reforms directly related to the idea of justice were the judicial and commercial-financial reforms. The organizational reforms put into practice in line with the intentions declared in the Edicts were radically changing the Ottoman political structure with other organizational reforms. ${ }^{56}$

These legalizations were sought to be implemented within the framework of the principles predicted by the Islamic law and appropriated by the Ottoman Empire. ${ }^{57}$ According to this, the decisions were given within the frame of the legislative power of the sultan as in the Ottoman tradition. Some rules of the Islamic Jurisprudence (fıkıh) became the codes of law in the enactment activities, a significant pillar of the structural reforms after the Tanzimat Edict, however; some laws were imported from the West, especially from France, and structural reforms were carried out based on these laws. In a general sense, it is probable to say that personal right and security and legal justice were in the background of the structural reforms of the Tanzimat Era. The state had interpreted personal right and security and legal justice in the classical period based on Islamic Jurisprudence ( $\left.f_{1} k_{1} h\right)$ but these took a positivist form in Europe.

The criminal codes constituted the most crucial stride of the Tanzimat Era enactments. The first of the criminal codes of this Era intended to fill the gaps in criminal law and to introduce reforms was enacted in 1840. In this code, the penalties for crimes committed public officials were regulated. The second one was the 1851 dated New Penal Code (Kanun-1 Cedid). There were no changes in this law other than those in the first one. It annulled numerous fines. In this respect, it was significant in terms of transitional justice. The most vital change made by this code was that

${ }^{54}$ Tahiroğlu, "Tanzimat'tan Sonra Kanunlaştırma Hareketleri" For literature on activities of enactment, see: Mustafa Şentop, “Tanzimat Dönemi Kanunlaştırma Faaliyetleri Literatürü", Türkiye Araştırmaları Literatür Dergisi 3/5 (2005): 647-672.

${ }^{55}$ Şerif Mardin, Religion, Society and Modernity in Turkey (Syracuse, N.Y.: Syracuse University Press, 2006).

${ }^{56}$ Stanford J. Shaw - Ezel Kural Shaw, History of the Ottoman Empire and Modern Turkey: Volume 2, Reform, Revolution, and Republic: The Rise of Modern Turkey 1808-1975 (Cambridge U. K.: Cambridge University Press, 1977), 77-78.

${ }^{57}$ Aydın, M. A. (2010), Türk Hukuk Tarihi (İstanbul: Beta, 2010), 420-423. 
public prosecution understanding was introduced. ${ }^{58}$ The main aim of these criminal codes was to build a state of law. For this purpose, many steps promised in Tanzimat were made with this law. The third one was the 1858 dated Imperial Criminal Code (Ceza Kanunname-i Hümayunu). ${ }^{59}$ This code prepared by a commission had a composite structure. The 1810 dated French Criminal Code influenced it. It was wide and comprehensive in comparison with the preceding ones. Outside of these criminal codes, new commercial codes inspired by the French Commercial Code were made in 1840 and 1850 . The obligations, verdicts partly related to property and personal laws, were enacted by the name of the Ottoman Code of Civil Law (Mecelle-i Ahkam-i Adliyye) prepared between 1868-1876. Afterwards, the verdicts of the family law were enacted by the name of Decree of Family Law (Hukuk-1 Âile Kararnâmesi) in 1917. With these two codes, the issuebased principles of Islamic law were enacted in the modern form for the first time. Furthermore, in 1864 and 1871, the Provincial Regulation (Vilayet Nizamnamesi), imitating the administrative structure of the French system, was published to put the provincial administration in order. With these regulations, the governors of the provinces were equipped with numerous powers and the sanjak, district and the village system was imported. Councils were formed to administer these centers. Representatives of Muslim and non-Muslim subjects took their places among the members of these councils. These representatives, containing two persons outside of administrators and community leaders, were determined by election. Municipalities had also be formed, as per this regulation. In 1847, that boys and girls would receive equal share from their father's inheritance was accepted in the Title-Deed Regulation (Tapu Nizamnamesi) prepared with the decree of the sultan. In 1864, based on the French Press Code, the Press Regulation (Matbuat Nizamnamesi) was declared; however, these regulations were issued in order to track the increasing publications of magazines and newspapers.

In the edicts of Tanzimat era and all judicial reforms, the concept of modern citizenship and the rights stemming from citizenship took part for the first time, it was particularly expressed that all Ottoman subjects were assured to have their rights without discriminating between religions and races, and some privileges were removed. ${ }^{60}$ In 1853, non-Muslims were giv-

${ }^{58}$ Akyıldız, "Tanzimat", 40: 7-10.

${ }^{59}$ Gabriel Baer, "The Transition from Traditional to Western Criminal Law in Turkey and Egypt," Studia Islamica, 45 (1977): 142.

${ }^{60}$ Bernard Lewis, The Emergence of Modern Turkey (London: Oxford University Press, 1965). 
en different privileges and opportunities of witnessing and becoming member in the courts. It was decided to apply the principle that the tax was collected in comparison with the power of everyone and no one was demanded to pay extra. Injustices regarding military service were accepted and it was pledged to make regulation. Since, it had been grumbled about the uncertain length of the military service and randomly recruiting soldiers. It was emphasized that this application had a negative influence on agriculture, trade and population growth and that length of military service had to be determined as four or five years. Death penalty without judgment was abolished. Confiscation was also annulled. Salaries of officers were ameliorated to some extent. It was decided that the military regulations would be negotiated and determined in the Military Council. ${ }^{61}$ In February 1861, it was declared that the justice and tax system would be reformed. In 1858, homosexuality was no longer taken into account as a crime. The most essential concrete stride regarding non-Muslims was taken after the events happened between the Maronites and the Druzes living in Lebanon. After these incidents, a special regulation was published for Lebanon due to the pressure of European states and a Christian governor was assigned to this district for the first time. This governor having the title of pasha held a degree of vizier. Community regulations were prepared for the Greeks in 1860, for the Armenians in 1863 and for the Jewish in 1865 . Hence, each community had the power to form a council to do their administrative works. With this stride, it was intended to achieve unity between communities and religious groups and to increase loyalties of these communities and groups to the state. Special attention was paid in order not to clash new laws and regulations with the old ones. When new institutions were opened, old institutions were not closed and both institutions were run together for a while. The new laws were first tested in regions such as Bursa and Edirne in which the central authority was powerful.

\section{STRUCTURAL REFORMS IN THE TANZIMAT ERA}

The essential reform needs concerning the judicial system came thoroughly to light before the Tanzimat era. ${ }^{62}$ In order to fulfill this purpose, sequences of complementary steps were taken. The most significant of these steps was the creation of the Supreme Council of Judicial Ordinances

${ }^{61}$ Aky1ldı, "Tanzimat”, 40: 7-10.

${ }^{62}$ Bogaç A. Ergene, "On Ottoman Justice: Interpretations in Conflict (1600-1800)", Islamic Law and Society 8/1 (2001): 52-87. 
(Meclis-i Vâlâ-yı Ahkâm-1 Adliye) on March 23, $1837 .{ }^{63}$ The duty of this council was to make new laws and to audit the practice of the articles of Tanzimat after the declaration of the Tanzimat Edict. This council was also able to judge. ${ }^{64}$ The council, serving as an administrative jurisdiction, had the duty of judging civil servants and solving disputes between the state and the individuals. The General Supreme Council (Meclis-i Âlî-i Umûmi) was formed immediately after the announcement of the Tanzimat. Leading statesmen and the members of the Supreme Council (Meclis-i Vâlâ) took place in this assembly, chaired by the Grand Vizier. This council was a high consultative and decisional organ.

The councils that could be regarded as the foundation of the Nizamiye Courts were established in 1840; both Muslim and non-Muslim judges were assigned to these courts. ${ }^{65}$ Additionally, the Council of Accounting (Meclis-i Muhasebe) was established in 1840 under the Ministry of Finance. The duty of this council was to control the goldsmiths and to solve disputes. In 1847, various provincial councils were founded to resolve the commercial problems of people living in the provinces. Further, in 1847, hybrid criminal courts composed of Muslims and non-Muslims were formed to rule cases of all Ottoman subjects. These courts heard all criminal cases except the death penalty of all Ottoman citizens and foreign nationals. Approval of the sultan was required only in the death penalty. In the cases regarding foreigners, the consulate officer of the foreign country would be present at the court. Embassy or consulate officers were among the members of this council. ${ }^{66}$

The other significant step concerning organizations was the Council of Investigation (Meclis-i Tahkik), formed in 1854 in Istanbul. The duty of this council was to hear criminal proceedings. Its provisions outside of death penalty were irrevocable and had to be applied immediately. Proceedings requiring heavy punishments such as death penalty were sent to the Supreme Council of Judicial Ordinances (Meclis-i Ahkâm-1 Adliye) and if the death sentence became definite, this punishment would be applied with the approval of the sultan. Afterwards, the power to prepare the law was trans-

${ }^{63}$ Zafer Toprak, "From Plurality to Unity: Codification and Jurisprudence in the Late Ottoman Empire," Ways to Modernity in Greece and Turkey: Encounters With Europe, 1850-1950, (2007): 32.

${ }^{64}$ Iris Agmon, "Social Biography of a Late Ottoman Shari'a Judge", New Perspectives on Turkey 30 (ed 2004): 83-113.

${ }^{65}$ Ertaş, Osmanlı İmparatorluğu'nda Diyarbakır Ermenileri, 182.

${ }^{66}$ Ekrem Buğra Ekinci, “Tanzimat Devri Osmanlı Mahkemeleri”, Yeni Türkiye 31 (2000): 764773. 
ferred to the High Council of Tanzîmât (Meclis-i Âlî-i Tanzîmât) in 1854. Two councils were united in 1861. The High Council of Tanzîmât (Meclis-i Âlî-i Tanzîmât) with the Supreme Council (Meclis-i Vâlâ) was united under the title of the Supreme Council of Judicial Ordinances (Meclis-i Ahkâm-1 Adliyye). In 1868, the Supreme Council (Meclis-i Vâlâ) was split in two. Instead of this, the Council of State (Şura-yı Devlet) and the Supreme Court of Appeal (Divan-1 Ahkâm-1 Adliye) were formed to hear the suits brought against the state officials. In both councils, there were representatives from all classes and subjects among their members and this council functioned as a court of appeals. Then, the Ministry of Justice was established in place of the Supreme Court of Appeal (Divan-1 Ahkâm-1 Adliye).

\section{CONCLUSION AND EVALUATION}

Taking the Ottoman Tanzimat and US Reconstruction Eras into consideration as cases in the context of transitional justice, we examined what the Ottoman Empire and the USA took legal steps for the sake of the practice of justice and carried out organizational reforms. By taking the legislative steps taken and organizational reforms in the reconstruction era resulted in failure into account, it is possible to evaluate the period as a missed chance for the US society. In spite of this situation, it can be said that the steps taken for the sake of justice in this process today are an inspirer for similar legal debates. In fact, American society carried on facing numerous discussed and unsolvable problems of the period for approximately a hundred years and reforms of the Reconstruction Era became the basis of the laws of equality in civil rights discussions in the 1950s and 1960s. With the Civil Rights Movement, the Americans were compelled to find solutions to these problems again.

If we come to the reasons of why the process failed, we can say that the rising opposition to the reforms in the Reconstruction Era and the economic crisis were the main factors of this failure. That numerous white Americans could not endure equally sharing power and being equally treated with the former slaves in the business disputes was the reason behind this opposition. That assertive economic development and school construction programs augmented taxes and state debt and economic recession led to corruption was also the reasons of why the process failed.

Another reason for the above-mentioned failure was the Southern

Republicans' attitude towards the protection of the rights retained. Some of the Northern Republicans thought that that former slaves and Afro- 
Americans gained the right to vote and to take state office was the violation of republicanism. These Republicans' attitudes towards the decisions taken about blacks and towards the pressures of organizations supporting violence were also among the reasons for the failure of the process. Additionally, the fact that the federal government did not take sufficient military measures against the violence committed by the Southern whites was among the reasons of the failure of the process. According to some historians, the fact that the Republican coalition did not contain the Southern states was a reason for the failure. Additionally, the fact that the problems of former slaves to have property could not be solved and the required legal regulations for this were delayed was among the reasons of the failure.

As in the Reconstruction Era, the chief target of the Tanzimat Era reforms was to fortify the state, to sustain stability and to get the society united by overcoming the existing questions by means of law. Even if wideranging reforms brought about with the influence of foreign interventions and internal incentives remained inconclusive, the steps taken for the sake of transitional justice became an inspirer for the reforms in the period of the Constitutional Monarchy, the proclamation of the Ottoman Constitution of 1876 (Kanun-i Esasî), and even for the reforms of the Republican period. The primary aim of the reforms of the Tanzimat Era was to ensure survival of the state and to unite the society. To realize this purpose, diverse segments of the society were included in different administrative councils and thus gained an opportunity to have a say in the government. Nevertheless, even though different steps were taken to curb the authority of the sultan, it is necessary say that the Ottoman state carried on to be governed by the absolute monarchy grounded on the authority of the sul$\tan$. However, it is probable to say that a powerful bureaucratic structure constituted against the Sultan. Different regulations in the field of freedom and law, the decrease of arbitrary implementations, the restriction of the slave trade, and the dissemination of the idea of equality were some of the positive outcomes.

It can be said that that the institutional infrastructure required in the road to reform had not constituted was effective upon why the reforms in the Tanzimat period resulted in failure. From angle of the period, Ottoman society did not yet have a sense of political community, political party structure, and civil society organization. The organization of reforms outside of the sultan's government was depended on the personal endeav- 
ors of bureaucrats. One of the most significant problems encountered by the state in the sense of reforms was the separations induced by the idea of nationalism. To apply the Tanzimat reforms realized to prevent the disintegration of the Ottoman nation and to keep the nation together was extremely difficult because it, first of all, necessitated an Ottoman belonging.

Finally, it is possible to reach the conclusion that an attempt was made in both periods in order to face and remove the traumas of the past, which was one of the most crucial parameters of the transitional justice. The strides taken in both eras became a part of cardinal political changes. Diverse legal, administrative and political changes, all of which were mentioned above, were made and in spite of their various forms, it was made efforts to prevent violations of the rights experienced in the past and to indemnify the unjust treatments. This was why various reform strategies were determined for the future. It is also seen that the concept of human rights and the determination practices of unjustly treated people to compensate their losses, both of which were at the center the applications of the transitional justice, were attempted to be realized in terms of practices even if these practices were not systematic. Even if this period resulted in failure, referring to the period in numerous constitutional and legal reforms undoubtedly indicates the significance of the strides taken. Both cases demonstrate that searches for justice are not restricted to modern and democratic regimes and indicate that it is not necessary to be limited to modern regimes in order to benefit from the implementations of the transitional justice.

\section{BIBLIOGRAPHY}

Abu-Manneh, Butrus. "The Islamic Roots of the Gülhane Rescript". Die Welt des Islams 34/2 (1994): 173-203. https://doi.org/10.2307/1570929.

Agmon, Iris. "Social Biography of a Late Ottoman Shari'a Judge". New Perspectives on Turkey 30 (ed 2004): 83-113. https://doi.org/10.1017/S0896634600003927.

Akça, Gürsoy - Hülür, Himmet. “Tanzimattan Cumhuriyete Siyasal ve Hukuksal Yapının Modernleşmesi". Selçuk Üniversitesi Türkiyat Araştırmaları Dergisi. 21 (2007): 235-269.

Akiba, Jun. “Kadılık Teşkilatında Tanzimat'ın Uygulanması: 1840 Tarihli Ta'limname-i Hükkam". Osmanlı Araştırmaları 29/29 (2007).

Akyıldız, Ali. Osmanlı Bürokrasisi ve Modernleşme. İstanbul: İletişim Yayınları, 2004.

Akyıldız, Ali. "Tanzimat”. Türkiye Diyanet Vakfı İslam Ansiklopedisi. 40: 1-10. İstanbul: TDV Yayınları, 2011. 
Aoláin, Fionnuala Ní - Campbell, Colm. "The Paradox of Transition in Conflicted Democracies". Human Rights Quarterly. 2005. 172-213.

Aydın, M. A. (2010). Türk Hukuk Tarihi. İstanbul: Beta, 2010.

Aydın, M. Akif. "Kanunnameler ve Osmanlı Hukuku'nun İşleyişindeki Yeri”. Osmanlı Araştırmaları 24/24 (2004).

Baer, Gabriel. "The Transition from Traditional to Western Criminal Law in Turkey and Egypt". Studia Islamica 45 (1977): 139-158.

Bales, Kevin. Buying Freedom: the Ethics and Economics of Slave Redemption. Princeton, NJ: Princeton University Press, 2007.

Barreyre, Nicolas. "The Politics of Economic Crises: The Panic of 1873, the End of Reconstruction, and the Realignment of American Politics". The Journal of the Gilded Age and Progressive Era 10/4 (2011): 403-423.

Bedir, Murteza. "Fikih to Law: Secularization Through Curriculum". Islamic Law and Society 11/3 (2004): 378-401.

Berkes, Niyazi. The Development of Secularism in Turkey. Montreal [Québec]: McGillQueen's Press-MQUP, 1964.

Burton, Orville Vernon. The Age of Lincoln: A History. Hill and Wang, 2008.

Castel, Albert E. "Andrew Johnson". The Presidents: A Reference History. Ed. Henry Franklin Graff. 7. Bs. 225-239. New York-USA: Charles Scribner's Sons : Thomson/Gale, 2002.

Cimbala, Paul Alan - Miller, Randall M. The Freedmen's Bureau and Reconstruction: Reconsiderations. Fordham Univ Press, 1999.

Collins, Cath. Post-transitional Justice: Human Rights Trials in Chile and El Salvador. Penn State Press, 2010.

Downs, Jim. Sick from Freedom: African-American Illness and Suffering During the Civil War and Reconstruction. New York-USA: Oxford University Press, 2012.

Duthie, Roger. "Transitional Justice and Displacement". International Journal of Transitional Justice 5/2 (2011): 241-261.

Ekinci, Ekrem Buğra. “Tanzimat Devri Osmanlı Mahkemeleri”. Yeni Türkiye 31 (2000): 764-773.

Elster, Jon. Closing the Books: Transitional Justice in Historical Perspective. Cambridge U. K.: Cambridge University Press, 2004.

Ergene, Bogaç A. “On Ottoman Justice: Interpretations in Conflict (1600-1800)". Islamic Law and Society 8/1 (2001): 52-87.

Ertaş, Kasım. Osmanlı Imparatorluğu'nda Diyarbakır Ermenileri. İstanbul: Rağbet, 2015.

Farmer-Kaiser, Mary. Freedwomen and the Freedmen's Bureau: Race, Gender, and Public Policy in the Age of Emancipation. New York-USA: Fordham Univ Press, 2010.

Feyzioğlu, Hamiyet Sezer - Kılıç, Selda. “Tanzimat Arifesinde Kadılık-Naiplik Kurumu". Ankara Üniversitesi Dil ve Tarih-Coğrafya Fakültesi Tarih Bölümü Tarih Araştırmaları Dergisi 24/38 (2005): 31-53.

Fitzgerald, Michael W. Splendid Failure: Postwar Reconstruction in the American South. Ivan R Dee, 2007.

Fleischman, Richard - Tyson, Thomas - Oldroyd, David. “The US Freedmen's Bu- 
reau in post-Civil War reconstruction". Accounting Historians Journal 41/2 (2014): 75-109.

Fleming, Walter Lynwood. Documentary History of Reconstruction, Political, Military, Social, Religious, Educational \& Industrial, 1865 to the Present Time. Cleveland, Ohio: AH Clark Company, 1907.

Foner, Eric. Free Labor, Free Soil, Free Men: The Ideology of the Republican Party Before the Civil War. New York: Oxford University Press, 1970.

Gencer, Bedri. "Son Osmanlı Düşüncesinde Adalet". Muhafazakâr Düşünce Dergisi. 15 (2008): 123-147.

Gülener, Serdar. "Çatışmacı Bir Geçmişten Uzlaşmacı Bir Geleceğe Geçişte Adalet Arayışı: Geçiş Dönemi Adaleti ve Mekanizmalarına Genel Bir Bakış". Uluslararası Hukuk ve Politika 8/32 (2012): 43-76.

Gülsoy, Ufuk. "Islahat Fermanı". Türkiye Diyanet Vakfı İslam Ansiklopedisi. 19: 185190. İstanbul: TDV Yayınları, 1999.

Gümüş, Musa. “Anayasal Meşrûtî Yönetime Medhal: 1856 Islahat Fermanı'nın Tam Metin İncelemesi”. Türk Dünyası Sosyal Bilimler Dergisi 47 (2008): 215-240.

Gürsakal, Gürsu Galip. “Osmanlı ve Büyük Güçlerin Askeri Harcamalarına Karşılaştırmalı Bir Bakış (1840-1900)". Gazi Akademik Bakış 4/7 (2010): 115131.

Hamadeh, Shirine. "Ottoman Expressions of Early Modernity and the 'İnevitable' Question of Westernization". Journal of the Society of Architectural Historians 63/1 (2004): 32-51.

Hanioğlu, M. Şükrü. A Brief History of the Late Ottoman Empire. Princeton, NJ: Princeton University Press, 2010.

Hansen, Thomas Obel. "Transitional Justice: Toward a Differentiated Theory". Or. Rev. Int'l L. 13 (2011): 1.

Harrison, Robert. "New Representations of a 'Misrepresented Bureau': Reflections on Recent Scholarship on the Freedmen's Bureau". American Nineteenth Century History 8/2 (2007): 205-229.

Kolchin, Peter. "Scalawags, Carpetbaggers, and Reconstruction: A Quantitative Look at Southern Congressional Politics, 1868-1872". The Journal of Southern History 45/1 (1979): 63-76.

Lewis, Bernard. The Emergence of Modern Turkey. London: Oxford University Press, 1965.

Lieberman, Robert C. “The Freedmen's Bureau and the Politics of Institutional Structure". Social Science History 18/3 (1994): 405-437.

MacDonald, William. Select Charters and Other Documents Illustrative of American History, 1606-1775. Macmillan, 1910.

Mardin, Şerif. Religion, Society and Modernity in Turkey. Syracuse, N.Y.: Syracuse University Press, 2006.

Masur, Louis P. Lincoln's Hundred Days: The Emancipation Proclamation and the War for the Union. Harvard University Press, 2012.

McAdams, A. James. "Transitional Justice: The Issue That Won't Go Away". International Journal of Transitional Justice 5/2 (2011): 304-312. 
Nadolski, Dora Glidewell. "Ottoman and Secular Civil Law". International Journal of Middle East Studies 8/4 (1977): 517-543.

Oliver, Melvin - Shapiro, Thomas. Black Wealth/White Wealth: A New Perspective on Racial İnequality. Routledge, 2013.

Ortaylı, İlber. İmparatorluğun En Uzun Yüzyılı. İstanbul: Timaş Yayınları, 2008.

Pablo De Griff. "'Theorising Transitional Justice"”. Transitional Justice. Ed. Elster J, Nagy R, Williams M. NewYork: NYU Press, 2012.

Pearson, Reggie L. “'There Are Many Sick, Feeble, and Suffering Freedmen': The Freedmen's Bureau's Health-Care Activities during Reconstruction in North Carolina, 1865-1868". The North Carolina Historical Review 79/2 (2002): 141-181.

Perman, Michael. The Road to Redemption: Southern Politics, 1869-1879. Univ of North Carolina Press, 1985.

Ranney, Joseph A. In the Wake of Slavery: Civil War, Civil Rights, and the Reconstruction of Southern Law. Greenwood Publishing Group, 2006.

Rodriguez, Junius P. Slavery in the United States: A Social, Political, and Historical Encyclopedia. Abc-clio, 2007.

Salzman, Lawrence. "Civil Rights Act of 1866". Encyclopedia of American Civil Liberties. Ed. Paul Finkelman. 1. CRC Press, 2006.

Shaw, Stanford J. - Shaw, Ezel Kural. History of the Ottoman Empire and Modern Turkey: Volume 2, Reform, Revolution, and Republic: The Rise of Modern Turkey 1808-1975. Cambridge U. K.: Cambridge University Press, 1977.

Striner, Richard. Father Abraham: Lincoln's Relentless Struggle to End Slavery. Oxford University Press, 2007.

Şentop, Mustafa. "Tanzimat Dönemi Kanunlaştırma Faaliyetleri Literatürü". Türkiye Araştırmaları Literatür Dergisi 3/5 (2005): 647-672.

Tahiroğlu, Bülent. “Tanzimat'tan Sonra Kanunlaştırma Hareketleri”. Tanzimat'tan Cumhuriyet'e Türkiye Ansiklopedisi 3 (1985).

Tanör, Bülent. "Anayasal Gelişmelere Toplu Bir Bakış". Tanzimat'tan Cumhuriyet'e Türkiye Ansiklopedisi 1 (1985): 1789-1980.

Teitel, Ruti G. Transitional Justice. Oxford University Press, 2000.

Toprak, Zafer. "From Plurality to Unity: Codification and Jurisprudence in the Late Ottoman Empire". Ways to Modernity in Greece and Turkey: Encounters With Europe, 1850-1950. 2007.

Vapnek, Lara. The Politics of Women's Work in the United States, 1865-1909. Columbia University, 2000.

Webber, Jeremy. "Forms of Transitional Justice". Nomos 51 (2012): 98-128.

Zavodnyik, Peter. The Rise of the Federal Colossus: The Growth of Federal Power from Lincoln to FDR: The Growth of Federal Power from Lincoln to FDR. ABC-CLIO, 2011. 